\title{
Analysis of dose reduction of surrounding patients in Portable $\mathrm{X}$-ray
}

\author{
Deayeon Choe, Seongjin Ko, Sesik Kang, Changsoo Kim, Junghoon Kim, Donghyun Kim, Seokyoon Choe
}

Pusan catholic University

\section{Portable X-ray 검사 시 주변 환자 피폭선량 감소 방안 연구}

\author{
최대연, 고성진, 강세식, 김창수, 김정훈, 김동현, 최석윤 \\ 부산가톨릭대학교
}

\begin{abstract}
Nowadays, the medical system towards patients changes into the medical services. As the human rights are improved and the capitalism is enlarged, the rights and needs of patients are gradually increasing. Also, based on this change, several systems in hospitals are revised according to the convenience and needs of patients. Thus, the cases of mobile portable among examinations are getting augmented. Because the number of mobile portable examinations in patient's room, intensive care unit, operating room and recovery room increases, neighboring patients are unnecessarily exposed to radiation so that the examination is legally regulated. Hospitals have to specify that "In case that the examination is taken out of the operating room, emergency room or intensive care units, the portable medical X-ray protective blocks should be set" in accordance with the standards of radiation protective facility in diagnostic radiological system. Some keep this regulation well, but mostly they do not keep. In this study, we shielded around the Collimator where the radiation is detected and then checked the change of dose regarding that of angles in portable tube and collimator before and after shielding. Moreover, we tried to figure out the effects of shielding on dose according to the distance change between patients' beds. As a result, the neighboring areas around the collimator are affected by the shielding. After shielding, the radiation is blocked $20 \%$ more than doing nothing. When doing the portable examination, the exposure doses are increased $0^{\circ}, 90^{\circ}$ and $45^{\circ}$ in order. At the time when the angle is set, the change of doses around the collimator decline after shielding. In addition, the exposure doses related to the distance of beds are less at $1 \mathrm{~m}$ than $0.5 \mathrm{~m}$. In consideration of the shielding effects, putting the beds as far as possible is the best way to block the radiation, which is close to $100 \%$. Next thing is shielding the collimator and its effect is about $20 \%$, and it is more or less $10 \%$ by controlling the angles. When taking the portable examination, it is better to keep the patients and guardians far enough away to reduce the exposure doses. However, in case that the bed is fixed and the patient cannot move, it is suggested to shield around the collimator. Furthermore, $90^{\circ}$ of collimator and tube is recommended. If it is not possible, the examination should be taken at $0^{\circ}$ and $45^{\circ}$ is better to be disallowed. The radiation-related workers should be aware of above results, and apply them to themselves in practice. Also, it is recommended to carry out researches and try hard to figure out the ways of reducing the exposure doses and shielding the radiation effectively.
\end{abstract}

Key Words : Portable, Collimator shielding, tube angle, bed distance. 


\section{요야}

현대시대는 환자에 대한 의료제도가 의료서비스 개념으로 변화되고 있다. 이렇게 인간의 권리가 높아지고 환자가 고객이 되는 시대로 변화됨으로써 환자의 권리나 요구도 날로 증가되고 있으며 이를 바탕으로 여러 가지 병원 시스템 도 환자의 편의나 요구에 맞춰지고 있는 것이 현실이다. 이로 인해 일반촬영 검사 중 Portable 검사의 Case도 점차 증 가하고 있는 추세이다. Portable 검사의 Case가 증가하면서 병실, 중환자실, 수술실, 회복실에서 Portable검사로 인하 여 주변 환자들의 원하지 않는 의료 피폭이 발생하기 때문에 법적으로도 이를 규제하고 있다. 실제로 진단용 방사선 발생장치의 안전관리에 관한 규칙 중 방사선 방어시설의 검사기준에서 "수술실, 응급실 또는 중환자실 외의 장소에서 촬영할 경우 반드시 이동형 진료용엑스선 방어칸막이를 갖추어야 한다.”고 명시되어 있지만 이는 거의 시행되어지지 않고 있다. 따라서 X-ray Potable 검사를 통해 주변 환자가 받는 피폭선량을 알아보고 피폭선량 감소 방안을 알아보 고자 하였다.

본 연구는 Mobile Portable 장비에서 Collimator 주변을 차폐하여 차폐 전과 후의 선량 변화, Portable tube와 Collimator의 각도 변화에 따른 차폐 전과 후의 선량 변화, 환자 침대의 거리변화에 따른 차폐 전과 후의 선량 변화를 각각 측정한 뒤 차폐효과를 알아보았다.

연구 결과 Collimator 주변을 차폐한 후 선량 변화는 차폐하지 않았을 때보다 약 $20 \%$ 의 차폐효과를 보였다. Portable 검사 중 비 차폐 시 각도가 $0^{\circ}, 90^{\circ}, 45^{\circ}$ 순서로 피폭선량이 증가하였으며, 각도를 주었을 때 Collimator 주변

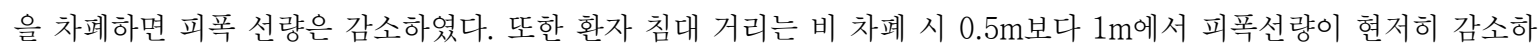
였고 침대 간 거리 변화 시 Collimator 주변 차폐 후 선량 변화는 감소하였다.

주변 환자 피폭선량 감소 측면에서 볼 때 침대거리를 가능한 멀리 떨어뜨리는 것이 가장 좋은 방법이며 차폐효과 가 약 $100 \%$ 내외로 상당한 효과를 볼 수 있다. 그 다음은 Collimator를 차폐하는 방법으로 차폐효과가 약 $20 \%$ 정도 를 나타내며, 각도를 제한하는 방법으로 약 $10 \%$ 내외의 효과를 나타낸다. Portable 검사 시 환자 피폭선량을 감소하기 위해 가능한 환자 및 보호자를 적정거리 이상으로 이동시킨 후에 실시하는 것이 가장 좋겠지만 환자가 움직일 수 없고 침대가 고정되어 있는 상태에서는 Collimator 주변을 차폐하는 방안을 제안한다. 또한 검사를 시행할 때 tube와 Collimator의 각도를 가능한 90 도로 시행하도록 하고 90 도가 안될 경우는 0도로 시행하되 45도는 가능한 지양하도록 한다.

방사선관계종사자들은 Portable 검사에서 위와 같은 결과들을 인식하고 실제 본인에게 적용시켜야 하며 효율적인 방사선 방어와 피폭선량을 감소시킬 수 있는 방안에 대한 노력과 연구에 힘써야 할 것으로 사료된다.

중심단어 : Portable, Collimator 차폐, Tube angle, 침대 거리.

\section{I. 서론}

\section{1. 연구 배경 및 필요성}

뢴트겐에 의한 X선의 발견으로 인하여 방사선이 의 료에 사용되어 왔고 현재도 의료부분에서 가장 기본 이면서 핵심적인 학문분야로 방사선이 이용되고 있다. 지난 100 여 년 동안 X선의 발견과 의료분야에서의 이 용은 생명을 위협하는 질병의 진료를 위해 방사선 피 폭을 감수하였지만, 방사선 덕분에 생명을 구한 사람 수는 헤아릴 수 없을 만큼 많았다. 지금 방사선은 의
학 분야에서 중요한 위치를 차지하게 되어 의학의 발 전과 더불어 질병의 진료에 크게 기여해 오고 있으며, 항생제와 함께 현대의학을 굴리는 두 바퀴 중의 하나 이다. 국민의 소득 수준의 향상으로 진료의 빈도가 늘 어나고 정교한 의료방사선 기술이 추가됨에 따라 환 자가 진료과정에서 피폭하는 의료 상 피폭은 증가하 는 추세에 있다 ${ }^{[1]}$. Portable 검사는 응급환자를 대상으 로 환자의 상태가 매우 위급하거나 시간을 다투는 상 황에서 응급 진단의 가장 기본적인 X-선 검사인 흥부 검사Chest $\mathrm{AP}$ )와 복부검사(Abdomen $\mathrm{AP})$ 등의 검사를 시행한다. 하지만 오늘날의 의료서비스에서는 환자가 단순히 의료를 제공받는 것을 초월하여 만족과 감동 
의 개념으로서 의료과정의 전반적인 부분에서 환자가 관섭하고 선택하고 있다. 이에 실제적으로 병원에서 환자가 검사실로 내려가는 검사를 거부한다거나 Portable 검사를 선택하거나 약간의 호흡곤란을 호소하 면 의사는 Portable 검사를 처방하게 된다. 따라서 오늘 날의 Portable 검사의 Case는 적은 수가 아니다. 이렇게 Mobile Portable 검사의 case가 날로 증가하면서 병실, 중환자실, 수술실, 회복실에서 Portable 검사로 인하여 주변 환자들의 원하지 않는 의료 피폭이 발생하고 있 다. 환자는 본인의 진단에 필요한 피폭 이외에 다른 피폭은 허용되어서는 안 된다. 또한 환자는 본인의 진 단에 의한 피폭 이외에 일반인의 연간허용피폭선량 $1 \mathrm{mSv}$ 미만과 동일하여야 한다 ${ }^{[2]}$. 따라서 진단용 방사 선 발생장치의 안전관리에 관한 규칙 중 방사선 방어 시설의 검사기준에서는 “수술실, 응급실 또는 중환자 실 외의 장소에서 촬영할 경우 반드시 이동형 진료용 엑스선 방어칸막이를 갖추어야 한다.”고 명시하고 주 변 환자의 피폭선량을 제한하고 있다 ${ }^{[3]}$. 하지만 병실 환자를 대상으로 Portable 검사를 시행할 때마다 이동 형 진료용엑스선 방어칸막이를 가지고 다니기거나 비 치하기에는 불가능하고 다른 방법으로 검사를 위해 환자를 각 병동마다 방사선 검사실을 따로 두어 침대 를 이동하여 검사하는 방법인데 실제적으로 시행되고 있는 병원도 있겠지만 거의 이행되어지지 않고 있다. Portable 검사를 시행할 때 옆 침대의 환자를 이동시키 고 검사를 하면 매우 이상적이지만 환자에 대한 몸과 연결된 선과 산소 튜브와 같은 장비들 때문에 이동이 매우 힘들며 검사마다 이렇게 환자를 옮기는 것은 작 업자의 검사시간의 효율성에서 매우 실행 가능성이 떨어진다. 따라서 주변 환자의 산란선 피폭선량을 경 감시키기 위해 노력을 해야 한다고 보고 Portable Collimator 주변을 차폐하여 차폐전후의 선량을 평가하 고 tube와 Collimator의 각도 변화에 따른 피폭선량 변 화 그리고 침대간 간격의 차이에 따른 피폭선량 변화 등을 분석한 뒤 방사선 차폐효과를 분석하여 적극적 인 방어 활동의 중요성을 제시하고, 향후 관련 분야의 기초 자료를 제공할 목적으로 본 연구를 시행하였다.

\section{2. 연구 목적}

Portable 검사가 날로 증가되어가고 있으며 이로 인
해 주변 환자들의 방사선 피폭선량은 증가되고 있다. Portable 검사를 시행하는 상황에서 건강상태가 매우 좋지 않거나 거동이 불편한 옆 침대 환자들은 방사선 피폭에 그대로 노출된다. 이에 본 연구의 목적은 Mobile Portable 장비에서 방사선이 조사되기 시작하는 Collimator 주변을 차폐하여 차폐 전과 후의 선량 변화, Portable tube와 Collimator의 각도를 변화에 따른 차폐 전과 후의 선량 변화, 환자 침대의 거리변화에 따른 차폐 전과 후의 선량 변화를 각각 측정한 뒤 차폐효과 를 분석해 보는데 있다. 이 연구 결과를 통하여 Portable 검사 중 Collimator 주변을 차폐한 차폐효과를 알아보고 검사를 위한 환자를 제외한 주변 환자의 피 폭선량을 최소로 할 수 있는 방안을 알아본 뒤 그 대 안을 제안하는 것이 본 연구의 목적이다.

\section{II. 연구 대상 및 방법}

\section{1. 실험 기기}

\subsection{Portable 장비}

본 연구에 사용된 Portable 장비 Mobile Portable (Mobilett XP Hybrid : SIEMENS)은 Fig 1 과 같이 이동 용 X선 장비로서 Tube와 제어판 그리고 이들을 연결 하는 Arm으로 구성되어 있다.

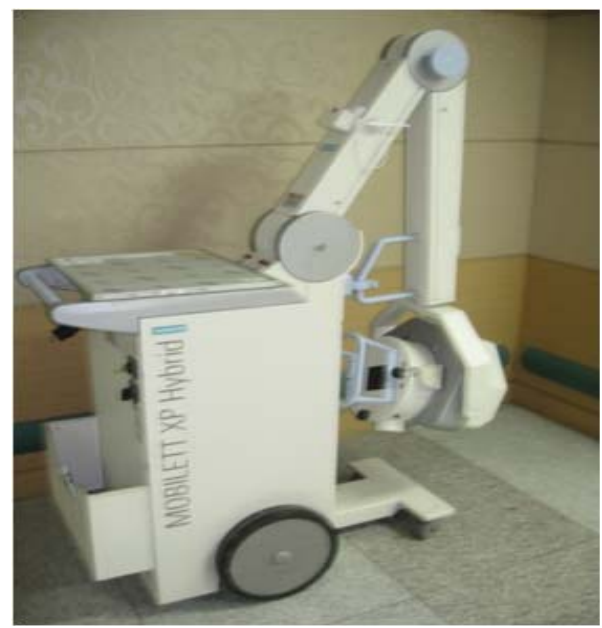

Fig 1. Mobile Portable 


\section{2 유리선량계(Glass Dosimetry) : Dose Ace (Type GD-352M : 진단용)}

광학유리선량계는 방사선에 조사된 은활성인산염 유리가 자외선에 의한 여기로 오렌지색 형광을 발하 는 현상(Radio Photo Luminecens, RPL)을 토대로 하는 적산형 고체선량계이며, 측정선량의 범위는 Cs-Y선을 기준으로 $10 \mu \mathrm{Gy}(\mathrm{Sv}) \sim 10 \mathrm{~Gy}(\mathrm{~Sv})$ 이다. 소형소자시스템은 소형선량계소자와 전용 Reader, 기타 판독 매거진, annealmagazine(재생처리용기), Preheat Tray, anneal용 전 기로, Preheat용 항온기 등으로 구성되어진 장비를 사 용하였다 ${ }^{[4]}$.
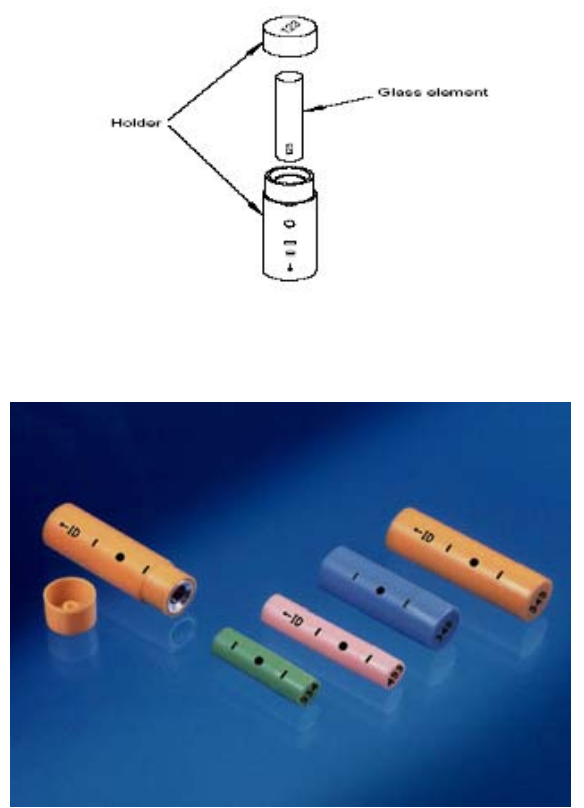

Fig 2. The strucuture of Glass Element and Holder3

\subsection{Rando phantom(피사체)}

Rando Phantom(Phantom Laboratory, USA)은 키 163 $\mathrm{cm}$, 몸무게 $54 \mathrm{~kg}$ 으로 $25 \mathrm{~cm}$ 간격으로 분리되어지며, 각 부위에 선량계를 삽입 할 수 있도록 고안되었으며 인 체와 유사한 등가물질로 구성 되어진 Phantom을 사용 하였다 ${ }^{[5]}$.

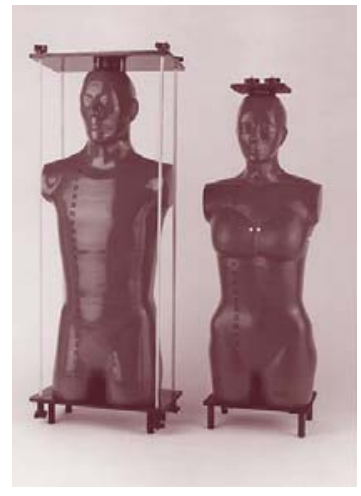

Fig 3. Rando Phantom

\section{4 차폐기구}

차폐 재료는 폐기된 납치마를 활용하였다. 납당량 은 $0.35 \mathrm{~mm}$ 이며 전체 무게는 $550 \mathrm{~g}$ 으로 기기에 부착을 해도 전혀 무리를 주지 않는다. 또한 반창고를 사용하 여도 무리 없이 부착이 가능하다. 다만 고정성이 없기 때문에 박스를 이용하여 각을 잡아 사용하였다. 자세 한 모형은 Fig 4와 같다.
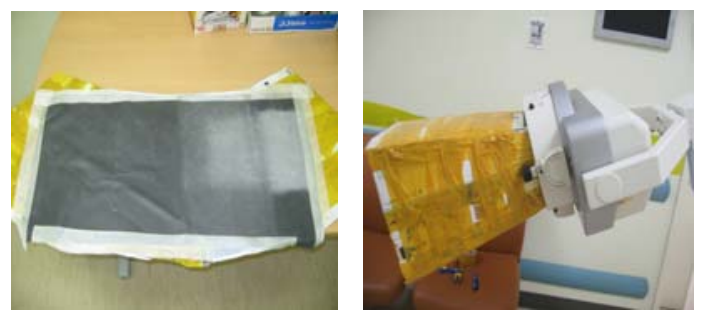

Fig 4. Used Apron \& Collimator shielding

\section{2. 실험 방법}

Mobile Portable 장비에서 방사선이 조사되기 시작하 는 Collimator 주변을 차폐하여 차폐 전과 후의 선량 변화, Portable tube의 각도를 $0^{\circ}, 45^{\circ}, 90^{\circ}$ 로 변화시켜 각도에 따른 차폐 전과 후의 선량 변화, 환자 침대의 거리를 $0.5 \mathrm{~m}$ 와 $1 \mathrm{~m}$ 로 변화시켜 거리에 따른 차폐 전과 후의 선량 변화를 각각 측정한 뒤 차폐효과를 알아보 았다. 검사 조건은 $\operatorname{Chest}(66 \mathrm{kVp}, 6 \mathrm{mAs})$, Abdomen $(80 \mathrm{kVp}, 12 \mathrm{mAs})$ 으로 고정한 후 각각 20 회씩 조사하여 산란선량을 측정하였다. 피사체는 Rando 팬텀을 사용 
하였으며, 선량계는 각도 0 도에서의 피사체와 동일한 위치와 높이를 유지하기 위한 가상의 환자를 만들어 유리선량계를 이용하여 정면과 우측 측면의 선량을 측정하였다.

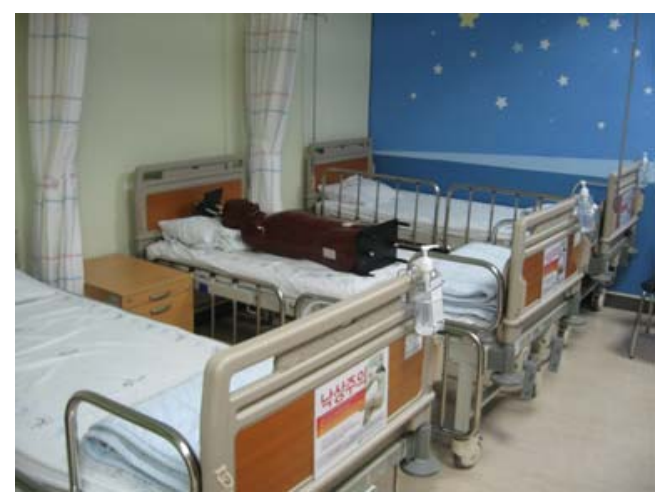

Fig 5. Beds in Patient's room

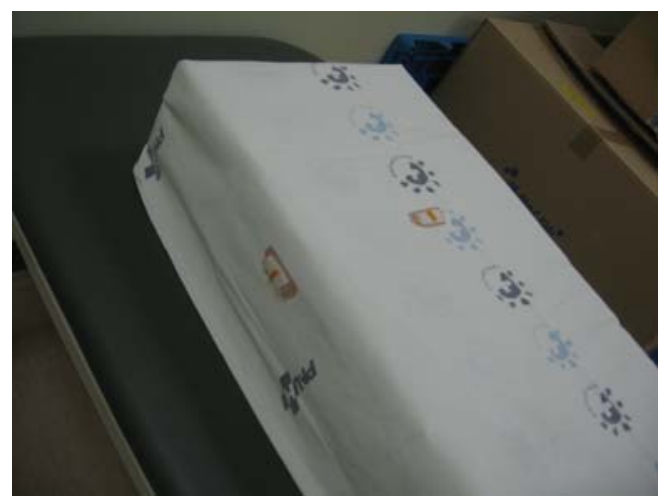

Fig 6. Imageing model of patient and glass dosimeter for dose measure

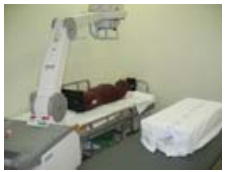

0도

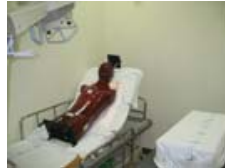

45도

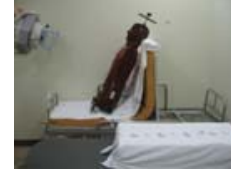

90도
Fig 7. Angels of portable exam

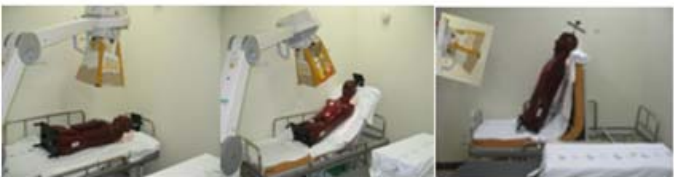

0도

45도

90도

Fig 8. Angels of portable exam after ollimator shielding

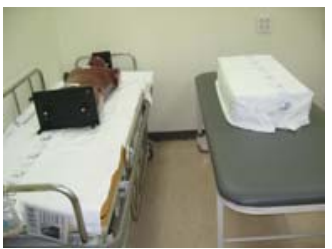

$0.5 \mathrm{~m}$

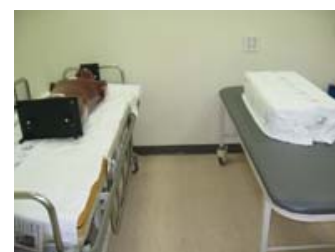

$1 \mathrm{~m}$
Fig 9. Difference of bed interval $(0.5 \mathrm{~m}, 1 \mathrm{~m})$

III. 결과

\section{1. 연구 대상의 분포}

실험 방법에 따라 차폐와 비 차폐에 따른 실험, tube 각도 차이에 따른 실험, 침대 간 간격 차이에 따른 실 험을 교차하여 총 108 회 실험을 하였고 실험 선량의 신뢰를 높이기 위해 3 회 촬영을 하여 평균값을 사용하 였다.

\section{2. 피폭선량 측정 결과}

\subsection{Collimator 차폐 유무에 따른 선량변화}

Collimator를 차폐하고 차폐 전후의 선량변화를 측 정한 결과 정면보다는 측면에서 피폭선량이 높았고 차폐를 하지 않았을 때 보다 차폐를 하였을 때 피폭선 량이 작았으며 차폐하지 않았을 때 보다 Chest 조건 $(66 \mathrm{kVp}, 6 \mathrm{mAs})$ 에서는 평균 $19.2 \%$, Abdomen 조건 $(80 \mathrm{kVp}, 12 \mathrm{mAs})$ 에서는 평균 $21.5 \%$ 정도의 차폐효과를 보였다. 
Table 1. Dose change of before and after shielding

- Chest (66kVp, 6mAs), Bed interval 0.5m

\begin{tabular}{|c|c|c|c|c|c|c|}
\hline \multirow{2}{*}{ 각도 } & \multicolumn{2}{|c|}{ 비 차폐 } & \multicolumn{4}{|c|}{ 차폐 } \\
\cline { 2 - 7 } & $\begin{array}{c}\text { 정면 } \\
(\mu G y)\end{array}$ & $\begin{array}{c}\text { 측면 } \\
(\mu G y)\end{array}$ & $\begin{array}{c}\text { 정면 } \\
(\mu G y)\end{array}$ & $\begin{array}{c}\text { 차폐율 } \\
(\%)\end{array}$ & $\begin{array}{c}\text { 측면 } \\
(\mu G y)\end{array}$ & $\begin{array}{c}\text { 차폐율 } \\
(\%)\end{array}$ \\
\hline $0^{\circ}$ & 64 & 114 & 54 & 18.51 & 101 & 12.9 \\
\hline $45^{\circ}$ & 93 & 140 & 83 & 12.1 & 114 & 22.8 \\
\hline $90^{\circ}$ & 69 & 85 & 65 & 6.2 & 72 & 18.1 \\
\hline
\end{tabular}

Table 2. Dose change of before and after shielding

- Abdomen (80kVp, 12mAs), Bed interval 0.5m

\begin{tabular}{|c|c|c|c|c|c|c|}
\hline \multirow{2}{*}{ 각도 } & \multicolumn{2}{|c|}{ 비 차폐 } & \multicolumn{4}{|c|}{ 차폐 } \\
\cline { 2 - 7 } & $\begin{array}{c}\text { 정면 } \\
(\mu G y)\end{array}$ & $\begin{array}{c}\text { 측면 } \\
(\mu G y)\end{array}$ & $\begin{array}{c}\text { 정면 } \\
(\mu G y)\end{array}$ & $\begin{array}{c}\text { 차폐율 } \\
(\%)\end{array}$ & $\begin{array}{c}\text { 측면 } \\
(\mu G y)\end{array}$ & $\begin{array}{c}\text { 차폐율 } \\
(\%)\end{array}$ \\
\hline $0^{\circ}$ & 33 & 80 & 27 & 22.2 & 65 & 23.1 \\
\hline $45^{\circ}$ & 49 & 86 & 37 & 32.4 & 71 & 21.1 \\
\hline $90^{\circ}$ & 33 & 55 & 28 & 18 & 49 & 12.2 \\
\hline
\end{tabular}

\subsection{Tube 각도 차이에 따른 선량변화}

Portable 검사 시 각도가 측면에서는 $45^{\circ}, 0^{\circ}, 90^{\circ}$ 순 서로 피폭선량이 컸다. 또한 각도를 주었을 때 모든 각도에서 Collimator 주변 차폐 후 피폭선량은 감소하 였고. 차폐효과를 나타냈다. 환자의 측면에서 받는 각 도 별 차폐효과는 $45^{\circ}$ 에서 $22.8 \%$ 로 가장 차폐효과가 높았고 다음이 $90^{\circ}$ 에서 $18.1 \%, 0^{\circ}$ 에서 $12.92 \%$ 로 환자 측면에서 각도별 차폐효과가 가장 낮았다. 하지만 침 대 간 거리가 $1 \mathrm{~m}$ 일 경우에는 위의 결과와는 조금 달 랐다. $90^{\circ}$ 에서 $42.5 \%$ 로 가장 차폐효과가 높았고 다음 이 $0^{\circ}$ 에서 $20 \%, 45^{\circ}$ 에서 $6 \%$ 로 환자 측면에서 각도별 차폐효과가 가장 낮았다.

\section{3 침대 간 간격 차이에 따른 선량변화}

환자 침대 간 거리는 $0.5 \mathrm{~m}$ 보다 $1 \mathrm{~m}$ 에서 피폭선량이 감소하였고 Collimator 주변 차폐 후 피폭선량 변화 역 시 $0.5 \mathrm{~m}$ 보다 $1 \mathrm{~m}$ 에서 피폭선량이 감소하였다. 또한 위 의 1.2 의 결과에서와 같이 침대 간 간격이 $0.5 \mathrm{~m}$ 와 $1 \mathrm{~m}$ 에 따른 각도 별 차폐효과는 각각 달랐다.
Table 3. Dose change to distance of bed interval

- Chest(66kVp, 6mAs), Bed interval 1m

\begin{tabular}{|c|c|c|c|c|c|c|}
\hline \multirow{2}{*}{ 각도 } & \multicolumn{2}{|c|}{ 비 차폐 } & \multicolumn{4}{|c|}{ 차폐 } \\
\cline { 2 - 7 } & $\begin{array}{c}\text { 정면 } \\
(\mu G y)\end{array}$ & $\begin{array}{c}\text { 측면 } \\
(\mu G y)\end{array}$ & $\begin{array}{c}\text { 정면 } \\
(\mu G y)\end{array}$ & $\begin{array}{c}\text { 차폐율 } \\
(\%)\end{array}$ & $\begin{array}{c}\text { 측면 } \\
(\mu G y)\end{array}$ & $\begin{array}{c}\text { 차폐율 } \\
(\%)\end{array}$ \\
\hline $0^{\circ}$ & 42 & 54 & 36 & 16.7 & 45 & 20 \\
\hline $45^{\circ}$ & 34 & 53 & 29 & 17.24 & 50 & 6 \\
\hline $90^{\circ}$ & 44 & 57 & 33 & 33.4 & 40 & 42.5 \\
\hline
\end{tabular}

Table 4. Dose change to distance of bed interval

- Abdomen(80kVp, 12mAs), Bed interval 1m

\begin{tabular}{|c|c|c|c|c|c|c|}
\hline \multirow{2}{*}{ 각도 } & \multicolumn{2}{|c|}{ 비 차폐 } & \multicolumn{4}{|c|}{ 차폐 } \\
\cline { 2 - 7 } & $\begin{array}{c}\text { 정면 } \\
(\mu G y)\end{array}$ & $\begin{array}{c}\text { 측면 } \\
(\mu G y)\end{array}$ & $\begin{array}{c}\text { 정면 } \\
(\mu G y)\end{array}$ & $\begin{array}{c}\text { 차폐율 } \\
(\%)\end{array}$ & $\begin{array}{c}\text { 측면 } \\
(\mu G y)\end{array}$ & $\begin{array}{c}\text { 차폐율 } \\
(\%)\end{array}$ \\
\hline $0^{\circ}$ & 13 & 29 & 11 & 18.2 & 21 & 38.1 \\
\hline $45^{\circ}$ & 15 & 27 & 12 & 25 & 23 & 17.4 \\
\hline $90^{\circ}$ & 14 & 27 & 11 & 27.3 & 19 & 42.1 \\
\hline
\end{tabular}

\section{$\mathrm{IV}$. 고찰}

본 실험에서는 Portalbe 검사를 시행하는 환자 주변 의 다른 환자에 대한 피폭선량 감소를 위해 Collimator 주변을 차폐하여 차폐 전과 후의 선량 변화, Portable tube와 Collimator의 각도 변화에 따른 차폐 전과 후의 선량 변화, 환자 침대의 거리변화에 따른 차폐 전과 후의 선량 변화를 각각 측정한 뒤 차폐효과를 알아보 았다. 그 결과 Collimator 주변을 차폐한 후 선량 변화 는 차폐하지 않았을 때보다 약 $20 \%$ 의 차폐효과를 보 였다. Portable 검사 중 측면에서 비 차폐 시 각도가 $0^{\circ}$, $90^{\circ}, 45^{\circ}$ 순서로 피폭선량이 증가하였으며, 각도를 주 었을 때 Collimator 주변을 차폐하면 피폭 선량은 감소 하였다. 또한 환자 침대 거리는 비 차폐 시 $0.5 \mathrm{~m}$ 보다 $1 \mathrm{~m}$ 에서 피폭선량이 감소하였고 침대 간 거리 변화 시 Collimator 주변 차폐 후 선량 변화는 감소하였다.

산란선을 포함한 모든 방사선은 거리가 멀수록 선 량 감쇄효과를 보이는 거리 역자승 법칙이 적용된다 ${ }^{[6]}$. 위의 실험에서도 다른 실험방법보다 침대간 거리간격 을 멀리하면 거리 역자승 법칙에 의해 피폭선량 감소 뿐만 아니라 옆 환자의 차폐효과가 우수하다는 것을 알 수 있다. 
또한 Collimator 주변을 차폐함으로써 1차선속에서 발생되는 산란선과 가변형 선속 조절기의 조리개에서 부터 발생되는 산란선을 제거하는 효과를 가진다. 이 러한 산란선으로 인한 환자 피폭선량은 감소된다 ${ }^{[7]}$

Tube의 각도에 따른 주변 환자들의 선량 또한 조사 되는 방향에 따라 직접 또는 간접적으로 피폭을 주게 된다. 각도가 $0^{\circ}$ 일 경우 주변 환자가 받는 선량은 검사 를 위한 환자와 부딪혀 나온 산란선이 대부분이지만 각도가 45도인 경우 옆 침대 환자 방향으로 조사되기 때문에 검사를 위한 환자와 부딪혀 나온 선량 이외에 주변환자로 향하는 선량으로 주변환자의 피폭선량은 증가하게 된다.

의료용 방사선 피폭 저감화를 위한 노력으로 김관 태 $^{[8]}$ 등의 연구에서 방사선 검사 시 조사야를 줄이게 되면 줄이지 않았을 때보다 약 $77.8 \%$ 정도의 선량 감소 율을 보인다고 하였고, 정우경 ${ }^{[9]}$ 등의 연구에서는 촬 영횟수와 검사 시간이 피폭에 크게 좌우되지만 인위 적인 조절에는 한계가 있고, 설정조건이나 검사자의 인식정도에 따라 피폭선량을 줄일 수 있으므로 교육 과 관리가 필요하다고 하였다.

이와 같이 피폭 감소를 위해 여러 가지 방법이 있겠 지만 Portable 검사 시 환자 피폭선량을 감소하기 위해 가능한 주변 환자 및 보호자를 적정거리 이상으로 이 동시킨 후에 실시하고 반드시 필요한 검사를 실시하 되 검사자에 대한 방호장비 착용뿐만 아니라 선원 기 시부에 적당한 차폐체를 설치하며 ${ }^{[10]}$ Tube와 Collimator 의 각도를 가능한 90 도로 시행하도록 하고 90 도가 안 될 경우는 0 도로 시행하되 45 도는 가능한 지양하는 방 법 또한 Portable 검사 시 주변 환자의 피폭선량 감소 에 많은 기여를 할 것이라고 본다.

따라서 방사선관계종사자들에 대한 지속적인 교육 과 관리가 필요할 뿐만 아니라 방사선관계종사자들은 피폭에 대한 주의와 경계를 잊지 않아야 할 것이며 피 폭 감소에 대한 다양한 방안의 개발을 위해 항상 노력 해야 할 것이다.

\section{$\mathrm{V}$. 결론}

본 연구는 Portalbe 검사 중에 검사를 하는 환자 옆
의 다른 환자들의 피폭을 최소화 할 목적으로 Collimator 주변을 차폐하여 차폐 전과 후의 선량 변화, Portable tube와 Collimator의 각도 변화에 따른 차폐 전 과 후의 선량 변화, 환자 침대의 거리변화에 따른 차 폐 전과 후의 선량 변화를 각각 측정하고 차폐효과를 알아보았다. Collimator를 차폐하게 되면 차폐를 하지 않았을 때 보다 약 $20 \%$ 정도의 차폐효과를 볼 수 있 으며 검사조건이 증가할수록 차폐효과는 증가한다. 또 한 각도 차이에 따른 선량 변화 실험에서 차폐를 하지 않았을 때에는 45도에서 피폭선량이 가장 컸고 90 도와 0 도에서 비슷한 피폭선량을 나타냈다. 하지만 Collimator를 차폐 후의 각도 차이에 따른 차폐효과는 환자의 정면과 측면, 조건, 그리고 침대 간 거리변화에 따라 차폐효과가 매우 다양하기 때문에 실제 피폭선 량 감소 방안의 측면에서 적용하기에는 어렵다고 보 았다. 따라서 비 차폐 시 45 도 각도에서 옆 침대 환자 의 피폭선량이 크므로 Portable 검사 시 가능한 45도 각도를 지양해야 할 것이다. 침대 간 간격 차이에 따 른 선량 변화에서는 차폐를 하지 않았을 때 거리를 $0.5 \mathrm{~m}$ 에서 $1 \mathrm{~m}$ 로 침대 사이의 간격을 넓히는 것만으로 도 피폭선량을 반 이상으로 줄이는 효과를 나타내었 다. 또한 차폐를 하게 되면 차폐를 하지 않았을 때 보 다 약 $20 \%$ 정도의 차폐효과를 볼 수 있다. 또한 침대 간 거리가 멀수록 Chest 90 도 검사 시 옆 침대 환자의 차폐효과는 크게 증가하게 된다.

따라서 주변의 환자 피폭선량 감소를 위한 방안으 로 다음과 같은 결론을 내렸다. Portable 검사 시 피폭 선량을 감소시키는 가장 좋은 방법은 침대 간 거리를 $0.5 \mathrm{~m}$ 에서 $1 \mathrm{~m}$ 로 가능한 멀리 떨어뜨리는 방법이며 이 로 인하여 약 $100 \%$ 이상의 상당한 차폐효과를 나타낼 수 있었다. 다른 방법으로는 Collimator 주위를 납차폐 체로 차폐하는 방법으로 약 $20 \%$ 정도의 차폐효과를 나타내었다. 마지막 방법으로 각도에서 가능한 45 도를 지양하고 90 도가 안될 경우는 0 도로 시행하여야 하며 이러한 각도 제한을 통해 약 $10 \%$ 내외의 효과를 볼 수 있다. 따라서 Portable 검사 시 환자 피폭선량을 감 소하기 위해 가능한 환자 및 보호자를 적정거리 이상 으로 이동시킨 후에 실시하는 것이 가장 좋겠지만 환 자가 움직일 수 없고 침대가 고정되어 있는 상태에서 는 Collimator 주변을 차폐하는 방안을 제안한다. 
이상의 결과를 종합해 볼 때 방사선관계종사자들은 Portable 검사에서 환자와 본인은 물론이고 주변환자와 보호자의 방사선 피폭에 대한 방어와 피폭선량을 감 소시킬 수 있는 방안에 대한 노력과 연구에 힘써야 할 것으로 사료된다.

\section{참고문헌}

[1] ICRP 80. Radiation Dose to patients from Radiopharmaceuticals(국제방사선방호위원회 간행물 53의 추록2) 서문., 1997

[2] 보건복지부고시 제 4 조 6 항, 진단용 방사선 발생장치의 안전관리에 관한 규칙 중 방사선 관계종사자의 선량한도, 2006

[3] 보건복지부고시 제 4조 3항, 진단용 방사선 발생장치의 안전관리에 관한 규칙 중 방사선 방어시설의 검사기준, 2006

[4] Dose Ace Inc, Glass Dosimetry manual, 2011

[5] Phantom Laboratory, USA, Rando phantom manual, 2009.

[6] 권덕문, 김성수, 김화곤 등, 의료영상정보학, 대학서림 pp. 15-16, 1996

[7] 박수성, 김건상, 이관세 등, 진단방사선원리, 대학서림 pp. 142-147, 1998

[8] 김태관, 노현아, 황민호 등, 투시조영 검사 시 조사야 변화에 따른 선량 및 화질에 관한 연구, 전국 방사선사 춘계학숟대회집 pp. 146, 2011

[9] 정우경, 투시와 중재시술의 방사선 피폭과 저감화 방법, Korean Med Assoc J. Vol. 54, No12, pp. 1269-1276, 2011

[10] 고신관, 강병삼, 임청환, 중재적 방사선 분야 방호용구 차폐효과, 대한방사선기술학회지 pp. 213-219, 2005 